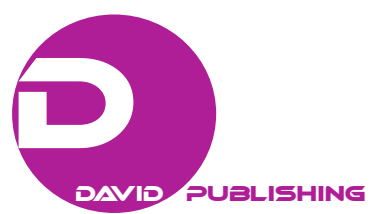

\title{
Global Dynamics of the China Dream and Possible Turkish-China Partnership on a New Silk Road to Renaissance by 2023
}

\author{
Andrew KP Leung \\ Andrew Leung International Consultants Ltd., Hong Kong SAR, China
}

\begin{abstract}
Turkey and China are two ancient civilizations with historic links in blood-line, trade, and strategic thinking. At the beginning of the 21 st century, both countries are at the crossroads of an epochal shift of world gravitas from the West to the East and from the advanced to the developing countries. China is set to overtake the United States as the world's largest economy probably within this decade. Under President XI Jinping, the country is pursuing a China Dream of renaissance in the coming years, harking back to China's glorious past. This resonates well with Turkey's ambition to achieve a similar goal by the hundredth anniversary of Ataturk in 2023. The horizon for cooperation is full of exciting possibilities, including high-speed rail from China's industrial seaboard passing through Turkey to the seaports in Western Europe; a customs-free expressway from the Western border of China through Kazakhstan and Belarus to Amsterdam; linking Bosphorus to China's world-leading container ports; investments in telecommunications and mining in the Central Asia region; partnership in a host of African "special economic zones" being managed by China; and capitalizing on the internationalization of the RMB, the Chinese yuan, to grow Istanbul to a world-class financial centre. In the light of these and other opportunities, there is no reason why areas of possible divergence between the two countries cannot be adequately managed. These include Turkey's cultural links with the Uyghur "separatists" in China's Xinjiang Province, membership of US- dominated North Atlantic Treaty Organization (NATO), and different approaches to international conflicts such as Syria. The Shanghai Cooperation Organization (SCO), in which China is playing a leading part, may be a strategic theatre where Turkey-China cooperation may be enhanced and their differences minimized. In short, as the tide of history is rapidly turning, Turkey and China are likely to find themselves as serendipitous partners on a New Silk Road to Renaissance in the coming decades.
\end{abstract}

Keywords: silk road, Renaissance, China dream, Eurasian high speed rail, Kazakhstan-Belarus expressway, Bosphorus, Shanghai Cooperation Organization, Uyghurs, North Atlantic Treaty Organization (NATO)

\section{Swing of History's Pendulum}

Until the late 19th century, the world's economy and political power was dominated by the Middle Kingdom, the Ottoman Empire and India. During the Ming Dynasty (1368-1644), for example, China's economy was the richest in the world both in aggregate and in per capita terms. During 1405-1433, Admiral

Andrew KP Leung, SBS, FRSA, International and Independent China Strategist; Chairman, Andrew Leung International Consultants Ltd.. 
ZHENG He, a Muslim eunuch, set sail seven times with a gigantic fleet of over 300 massive ships and 28,000 crewmen to spread China's culture and trade over the oceans to distant shores. The Ottoman Empire witnessed a similarly glorious chapter in its history. However, as from the nineteenth century, both the Middle Kingdom and the Ottoman Empire faced a terminal decline when the West's Industrial Revolution completely tipped the balance.

Now hegemony and empires have no place in a multi-polar world. But history's pendulum is swinging the other way. According to research by Banco Bilbao Vizcaya Argentaria (BBVA), a Spanish bank, the Emerging and Growth Leading Economies, including Turkey (EAGLEs) and NEST countries (upcoming-EAGLEs) are together expected to contribute $68 \%$ to world growth between 2012-2022. China and India are each expected to contribute a higher share than the US. The G7 economies together will add a mere 16\% (Annual Report, 2013). Goldman Sachs estimates that by 2050, the six EAGLEs combined economic weight, what may be called the E6, would be over two and half times more than the economies of US, Japan, United Kingdom and Germany combined.

\section{Dynamics of China's Rising Economic Power}

China's economy is already bigger than the rest of the BRICS (Brazil, Russia, India, China and South Africa) countries combined. According to the Economist, China is likely to overtake the United States as the world's largest economy by 2019 at market exchange rates. The International Monetary Fund (IMF) puts the date earlier, by 2016, on the basis of purchasing power parity (Reported in Mail Online of the Daily Mail, 2013). According to Global Sherpa statistics, by 2050 Turkey's economy, as the world's 10th largest, will be one notch higher than Japan (BRICS countries path to 2050, 2013).

As of February 2013, China has surpassed the United States as the world's largest trading nation (China Briefing, 2013). It has become the largest trading partner for 124 countries worldwide, including Association of Southeast Asian Nations (ASEAN) countries, Japan, Australia, Brazil and South Africa. As a sign of the times, the world's top 10 busiest container ports are mainly in China including Hong Kong, occupying the 1st, 3rd, 4th, 6th, 7th and 8th positions, a testament to the country's status as the centre of a global production and supply chain.

What is more, China accounts for $95 \%$ of the world's production of rare earths, which are essential in a host of electronics, electro-magnetic, and optical components for civilian as well as military applications including laser and nuclear batteries. In addition, China has become the world's largest gold producer.

\section{China's Burgeoning Consumer Power}

Perhaps the most remarkable feature of China's current growth is the dramatic rise of Chinese middle-class consumers.

According to the Brookings Institution (Kharas, 2011), China's middle-class (those with discretionary income) is expected to jump from $12 \%$ (157 million) to $70 \%$ of China's population by 2030 . China's mass affluent category (those with household income of $\$ 40,000-\$ 80,000$ in purchasing power parity terms) is expected to grow from $9.8 \%$ of the population in 2005 to $36.4 \%$ by 2025 , and $80 \%$ of them are under 45 years of age.

China became the world's largest car market by 2010. According to McKinsey, its sales of luxury cars are 
expected to surpass the United States by 2016. USA Today (January 2013) says Beijing will overtake Atlanta as the world's busiest airport by end 2013 while China will eclipse the United States in air traffic by 2030.

The McKinsey Global Institute reports (2013) that China is now the world's largest e-commerce market, worth $\$ 190$ billion in 2012. There are 130 million broadband accounts and six million e-merchants on Taobao, China's e-Bay, registering an annual compound growth of $120 \%$ since 2003.

According to a Reuters report, for the first time, consumption (55\%) exceeded investment (50\%) in contribution to China's GDP growth in October 2012. According to Credit Suisse, rising from a fairly low percentage $(36 \%)$ of the GDP at present, China's aggregate consumption is expected to surpass that of the United States by 2020, thanks to sheer size and accumulation of household wealth.

These dynamics are driven by the largest and fastest urbanization the world has even seen. According to McKinsey Global Institute (2008), China has been building 221 new third-and-fourth-tier cities in the inner provinces (many from villages and small towns) each with a population over one million by 2025, compared with only 32 cities of such size in the whole of Europe at present. Many of these new cities are inter-connected by new expressways and high-speed rail, absorbing massive migrants from the countryside. In 20 years, China will have added some 300 million urbanites, more than the entire population of the United States.

Given huge wage increases in recent years, mandated hikes in minimum wages by $13 \%$ annually through to 2015 , and expected relaxation of the household registration system of social provisions, these urban centers are likely to be China's engine of consumption growth in the coming decades. This is in line with a global trend. According to the Mckinsey Global Institute (2012), the world's 600 cities will generate $60 \%$ of global GDP by 2025.

\section{Is the China Dream Sustainable?}

China's President XI Jinping has repeatedly evoked the "China Dream", a rallying call to national renaissance harking back to China's glorious past. However, as China's previous Premier WEN Jia-bao pointed out repeatedly, China's development is "unstable, unbalanced, uncoordinated, and unsustainable". China is facing a multitude of challenges, including rampant corruption, abuse of power, acute inequalities, ecological degradation, deficits in the rule of law, human rights violations, limitations of freedom of expression, ethnic unrests, imbalance between investment and consumption, inefficient allocation of capital, and worsening relations with Asian neighbors. What is more, China's workforce is expected to dwindle by 2015 as her demographic dividend of a cheap labor pool is becoming exhausted with a fast-aging population profile, thanks to the One Child Policy. So is the China Dream attainable and sustainable?

In an article of 21 November, 2012 in Yale Global Online, professor David Shambaugh of George Washington University, Senior Fellow in the Foreign Policy Studies Program at the Brookings Institution, identified a number of what may seem insurmountable obstacles (Shambaugh, 2012).

The professor recognizes "a surprising strong consensus" both inside and outside China on a catalogue of what needs to be done-revamping China's economic growth model, breaking up state monopolies, nurturing civil society, reducing inequalities through adequate public goods like healthcare, old age pension, education, and environmental protection, safeguarding the rule of law, promoting better ethnic harmony in Tibet and Xinjiang, adopting a more accommodating and less confrontational posture in territorial disputes with Asian neighbors, and playing a more proactive role in global governance commensurate with the size of China's 
economy. However, he reckons that China's leaders are hamstrung by four inherent constraints.

\section{Path Dependency}

Shambaugh thinks that The composition of (China's) exports needs to move up the value chain —and this is linked to shifting investment from "hard" to "soft" infrastructure: education, science, cutting-edge technologies, innovation and cultural creativity. For China to make these transitions requires more than a shift in financial allocations, though, as it requires loosening of the political system, media censorship and civil society. A "knowledge economy" cannot easily be built in an authoritarian system.

\section{Soviet Shadow}

The professor argues that with the spectre of the collapse of the former Union of Soviet Socialist Republics (USSR), together with the lingering threats of the Eurasian "color revolutions" and the "Arab spring", there is a gripping fear that,

Opening the political system to genuine pluralism, empowering civil society, loosening media censorship, permitting free inquiry and critical thinking in education and research, or making the legislative and judicial systems autonomous of party control, would inevitable cascade out of control and spell the demise of party rule. (Shambaugh, 2013)

\section{Institutionalized Vested Interests}

Shambaugh opines that "The core problem is the state sector of the economy, which still accounts for roughly 30\% of GDP”. This includes state monopolies of the banking, energy, finance, defense, heavy industrial, aerospace, telecommunications, and much of the transportation sectors, as well as enormous swaths of land and property owned by the party, state and military. Lenin warned of "state-monopoly capitalism" in 1917 - China has it in spades today. These vested interests, particularly the 145,000 state enterprises and 120 "national champion" corporations, are not about to divest their interests voluntarily. In addition, "three other entrenched interest groups inhibit reforms: the military, the sprawling internal security apparatus and the arch-conservative wing of the Communist Party".

\section{Aggrieved Nationalism}

The professor refers to the "entrenched national narrative of victimization. This narrative, assiduously developed over six decades through the propaganda and educational systems, underpins the political raison d'etre of the Communist Party - but it is a core source of the frictions with China's neighbors and the West. China needs to shed this psychological baggage to truly normalize relations with Asia and the West - but to do so is to undercut the party's legitimacy". While Shambaugh's scepticism is well-placed, it must nevertheless be seen in the following context.

\section{On "Path Dependency"}

Since China started to reform and open up in 1978, the country's development has been a continuous work-in-progress to stay above waters of a continually changing tide. This perennial status of flux, of adaptation and change, has been at the core of China's economic miracle, compressing over a century's economic progress into a few decades.

As early as the beginning of China's 11th Five Year Plan (2006-2010), the leadership flagged up the so-called "five imbalances"- between rural development versus urban development, human development 
versus the environment, economic versus social development, national priorities versus local needs, and inward versus outward investments.

Since then, a swath of initiatives have been launched to hone "a nation of innovation", including a battle for talent and the promotion of the kind of "soft infrastructure" highlighted by Shambaugh: education, science, cutting-edge technologies, innovation and cultural creativity.

XU Li-yan and QIU Jing (2012) of the Samsung Economic Research Institute in China elaborated on this in a recent article for Yale Global,

China is determined to evolve into a global hub for innovation. With climbing college enrolment and a R\&D staff exceeding 1.5 million, the nation is reforming its higher-education system, hiring practices and immigration regulations; encouraging cooperation with industry; developing new majors in the sciences in areas like alternative energies and new-materials engineering; and offering incentives for Chinese students who studied overseas to return home. Plans are underway for 1200 education facilities - or "talent incubators"- for training technicians to be built in major cities by 2020 . The government is also funding initiatives to develop leaders in philosophy, social science, publishing, culture, the arts and heritage protection. The goal is to transform Chinese firms into multinationals ranking among the world's top companies and develop soft power. (Yale Global introduction to the author's article)

Indeed, China has been churning out some seven to eight million university graduates a year. According to the Centre for American Progress, by 2030 China will have some 200 million university graduates, more than the entire American workforce today (Cooper \& Hersh, 2012).

There has been a clear sense of changed direction since 2006 - now reinforced by the 12th Five Year Plan (2011-2015) - towards a dramatically different path based on slower but more balanced, higher-quality, more equitable and more sustainable growth.

In the current Five Year Plan (2011-2015), a total of 35 projects for various industries have been given support under seven broad strategic categories: energy saving and environmental protection; next generation IT; bio-industries; high-end assembly and manufacturing; new energy sources; new materials; and new-energy-powered cars.

There is a broad-based awareness that the cheap labor pool is dwindling and China must redouble efforts to respond to the challenges of the so-called "Lewis Turning Point"1 and the "Middle Income Trap"2.

What is perhaps ground-breaking evidence of the emergence of a knowledge-based economy is the 2012 Report of the World Intellectual Property Organization (WIPO) (World Intellectual Property Organization (WIPO) Report, 2012). This shows that for the first time in over a century, China as a developing country, tops the world in the filing of patents, trademarks and industrial designs. Eighty percent of these are home-grown. According to the Royal Society, China will surpass the United States in citations in scientific literature by end of 2013 (BBC News, 2012). "Path dependence" is by no means immutable.

\section{On the "Soviet Shadow"}

The Communist Party is caught in a quandary. What Daron Acemoglu and James Robinson describe as "extractive institutions" (Acemoglu \& Robinson, 2012) have generated growing social unrests that threaten to

\footnotetext{
1 The "Lewis Turning Point" is the period where a country's relatively cheap labor force is being exhausted and its economic growth model needs to change dramatically.

${ }_{2}$ The "Middle Income Trap" refers to the phenomenon where many developing countries see their economic growth stall within the per capita income range of $\$ 3,000-\$ 8,000$.
} 
undermine the stability of the whole regime. No change is clearly not an option. Uncharacteristically, a series of government about-turns have happened. Large projects approved in Beijing were allowed to be overturned in response to public protests against local land grabs and pollution. In particular, the so-called "Wukan model" of open and fair village elections was daringly promoted by Wang Yang. He is one of China's rising pro-reform "stars", now biding his time as a Vice Premier.

It is also instructive that a host of reform proposals in a new 468-page World Bank report (2012) were given the rare imprimatur of the State Council (Development Research Centre). These include the promotion of civil society, the role of the media to monitor governance (if initially only at the local level), and strengthening the rule of law.

Likewise instructive is the recent example of Foxconn, a Taiwanese "original equipment manufacturer" for Apple with 1.2 million workers in mainland China. According to a report in the Financial Times ${ }^{3}$, the company is allowed to get help from the US-based Fair Labor Association to train workers in voting for representatives on 18,000 union committees. Up to now, all workers on the mainland have been represented by the All-China Federation of Trade Unions, a state-backed unelected organ more on the side of the government and the management.

It is reported that Alexis de Tocqueville's "French Revolution" has been doing the rounds amongst China's top leadership, including Premier LI Ke-qiang and WANG Qi-shan, the newly-installed anti-graft czar. Fighting corruption was termed a matter of "life or death" for the Party and the nation by both out-going President HU Jin-tao and in-coming President XI Jin-ping at the 18th Party Congress.

The point here is that notwithstanding the "Soviet shadow", inertia against the momentum of the times will only threaten the whole regime's survival. So change has to happen and is already happening. More change is about to come.

\section{On Vested Interests}

The 18th Party Congress was unexpectedly delayed due to the shock of the BO Xi-lai affair. Regardless of factional vested interests, nothing concentrates the mind better than the very survival of the collective leadership. The moment of epiphany arrived that corruption and vested interests must be curbed, if not eradicated, including those represented by monopolistic state-owned enterprises which sap the vitality of the private sector. Indeed, this is one of the major reform recommendations highlighted in the World Bank/Development Research Centre report, of which Premier LI Ke-qiang is known to be a staunch supporter.

As for the military, a series of promotions and reshuffling of top generals took place before President Xi took over the Military Commission chairmanship in a first-of-its-kind complete power transfer at the 18th Party Congress. The Party's top leadership has reduced its numbers from nine to seven members, downgrading the security and propaganda apparatus below the level of the Politburo Standing Committee. The wings of some powerful vested interests have begun to be clipped.

All these changes are of course not enough to break the so-called "iron quadrangle" of the military, the security apparatus, state-owned enterprises and arch-conservatives. This is not totally unlike the American example of the military-industrial complex forewarned by President Eisenhower or its modern incarnation of

\footnotetext{
${ }^{3}$ Financial Times, 3 February, 2013.
} 
Capitol Hill, big business and Wall Street.

But in China, change for the better is on the horizon. Vested interests, when push comes to shove, can also trigger reform when whole regime stability is at stake.

\section{On Aggrieved Nationalism}

The nation's historical baggage is a reality borne of centuries of painful foreign oppression, which, amongst other deep psychological scars, has resulted, amongst other things, in the territorial disputes simmering today.

Over the past two decades, China has already settled her territorial disputes with Russia, preferring the forging of a semi-ally instead of hardening an implacable enemy along China's vast northern borders. The power dynamics in the Asia Pacific are more complex, involving geopolitics with America's recent "Pivot to Asia" and the whole question of vital sea lanes of communication. Territorial disputes there do not lend themselves to quick solution. In any case, territorial integrity is likely to remain a sore point in China' national psyche not amenable to easy compromise.

On the international front, China has simply grown too big to ignore her own role in the global commons. The country is the largest contributor of peace-keeping forces amongst Permanent Members of the Security Council. She is instrumental in brokering the six-party talks on North Korea and is recently beginning to take a keener interest in addressing conflicts in the Middle East.

Meanwhile, China is embarking on a mission to promote the country's soft-power, including Confucianism and other aspects of China's culture and heritage. However, notwithstanding the gravitas of China's economy and growing world-wide interests in the Chinese language, doubts remain about the merits of the so-called Beijing Consensus, even though China has repeatedly stressed that her own unique development model is not meant to be copied. In any case, until the country succeeds in showcasing a heart and soul that appeal to the spirit of the times, China is unlikely to have many unreserved followers.

In the final analysis, however, despite warts and all, The Economist in its front cover article of 27 October 2012 , states that

In the past 10 years under the current leader, HU Jin-tao, the economy has quadrupled in size in dollar terms. A new (though rudimentary) social safety net provides $95 \%$ of all Chinese with some kind of health coverage, up from just $15 \%$ in 2000. Across the world, China is seen as second in status and influence only to America. (The Economist, 2012)

A recent Organization for Economic Cooperation and Development (OECD) report (2012) suggests that "China will overtake the eurozone (in purchasing power parity terms) in 2012 and the US within the next four years, to become the largest economy in the world. By $2060 \ldots$ the combined GDP of China $(27.8 \%)$ and India $(18.2 \%)$ will be larger than that of the OECD ... the total output of China, India and the rest of the developing world $(57.7 \%)$ will be greater than that of developed OECD and (other) non-OECD countries (combined) $(42.3 \%)$ ".

So, huge challenges and problems notwithstanding, China's rise seems inexorable. It may still be too early to tell how China will evolve. But what is certain is that an epochal tide is clearly turning.

\section{Turning of the Tide}

Benn Steil's recent book The Battle of Bretton Woods (2013), expounds on how the world's tide last 
turned shortly before the end of the Second World War. At that time the old superpower Britain saw its strengths ebbing as the British Empire crumbled in India, the Middle East and other parts of the world. Due to War commitments and the destruction of its economy at home and abroad, Britain became highly indebted to the then-rising superpower, the United States. The Bretton Woods negotiations ended with the dismantling of the old Sterling Area in favor of free trade dominated by the United States and the dollar, sidelining the British Pound. This paved the way for subsequent years of American supremacy, which was later consolidated in 1989 with the collapse of the former USSR.

Now the tide is turning the other way, from the West to the East, from the developed to the developing countries, particularly China, and from US overall dominance to multilateralism, notwithstanding views in some quarters that the 21st will still remain essentially an American Century (Mahbubani, 2013) ${ }^{4}$.

Although China is for now many years behind the United States in comprehensive world power, China's indisputable ascendancy is perhaps exemplified by a recent research finding that the Renminbi (RMB), the Chinese yuan, has already eclipsed the dollar as an ipso facto "reference currency". More currencies now move in tandem with the RMB than with the greenback (Subramanian, 2012).

This is not surprising as China is at the heart of the world's globalized production and value chain. The situation is unlikely to change substantially even with "re-shoring" based on robotics and 3-D printing. For it would be immensely difficult to replicate a vast and efficient production base as China, supported by an efficient and comprehensive transportation infrastructure with a global reach. Moreover, China is also beginning to embrace 3-D printing technologies where appropriate, for example, in aeronautics.

The eclipse is also helped by China's strategy of hastening the RMB's internationalization, through currency swaps, use of the RMB for international settlements, and issuance of RMB-denominated bonds and other financial instruments. China's State Council has recently called for a detailed roadmap to achieve full convertibility of the RMB by $2015^{5}$. Pending this eventuality, some countries, including Australia and Japan, have already allocated a small percentage of their foreign currency reserves (5\% in the case of Australia) to the RMB.

Naturally, even with full convertibility, the RMB is unlikely to displace the dominant role of the US dollar anytime soon. However, even if the RMB becomes just one of several major international reserve currencies like the euro, the British Pound or the Japanese yen, the change in world dynamics is likely to be dramatic because of the sheer size of the Chinese economy. This is likely to be compounded by restrained or reduced investments by China in US treasuries. There seems an on-going attempt to get out of what Paul Krugman ${ }^{6}$, Nobel laureate in economics and New York Times columnist, calls "China's dollar trap" (Krugman, 2009).

\footnotetext{
${ }^{4}$ His remark is insightful that "China... remains largely a closed society (but with) an open mind while the United States is an open society with a closed mind". referring to the blind belief in some quarters that American dominance will remain unchanged.

5 China cabinet urges detailed yuan convertibility plan. (2013). Trading China, Thomson Reuters, 7 May, 2013. Retrieved May 17, 2013, from https://inside.thomsonreuters.com/Trading/china/Pages/Chinacabineturgesdetailedyuanconvertibilityplan.aspx

6 According to Krugman (2009), in order to manage excessive surpluses, China is locked into the trap of investing so much in US treasuries that any hasty withdrawal will see the value of treasuries and the greenback plummet, hurting China most of all. In an article Our Currency, Your Problem dated 30 April, 2005 for the Hoover Institution, Harvard University Professor Niall Ferguson reckoned that the Bush administration's combination of tax cuts and a global war on terror was being financed with a multibillion-dollar overdraft facility at the People's Bank of China (through China's huge purchase of Treasury bills), a kind of Chinese 'tribute' to the "American Empire". Retrieved May 28, 2013, from http://www.hoover.org/publications/hoover-digest/article/6386
} 


\section{Re-configured Geopolitics}

According to the National Intelligence Report-Global Trends 2025: A Transformed World (Global Trends 2025: A Transformed World, 2008) released in November 2008, while America's global leadership is likely to remain, its capacity to lead is declining, in the wake of the financial crises and wars in the Middle East. A host of rival powers is rising, including state and non-state actors, which necessitate America's working more closely with allies and non-allies in maintaining world order. This Report heralded the launch by former Secretary Hilary Clinton of America's "Pacific Century" which sees the United States returning to the Asia Pacific (Clinton, 2013). The term "Pivot to Asia" is now being very carefully avoided. According to Zbigniew Brzezinski, a doyen in foreign policy, President Obama has never used this terminology. Nevertheless, no matter what it is called, following the winding down of American entanglement in the Middle East, this new strategy represents a re-configuration of American assets to the Asia Pacific, a theatre which has been under China's growing influence in recent years but now considered most vital to US interest.

This reconfiguration has taken the form of boosting regional military, diplomatic and economic ties with a host of countries neighboring China, including the launch of a Trans-Pacific Partnership (TPP), which, tale-tellingly, initially excludes China. In response, China has supported a Regional Comprehensive Economic Partnership (RCEP) without the United States. This comprises the 10 ASEAN Members and its Free Trade Agreement Partners (Australia, China, India, Japan, the Republic of Korea and New Zealand) ${ }^{7}$.

The United States has also strengthened its military and other exchanges with Australia and India, which China understandably interprets as part a deliberate China encirclement or containment strategy.

Redoubled American military support has emboldened a number of Asian countries with long-standing territorial disputes with China. These include Japan over the Diaoyu/Senkaku islands in the East China Sea and Philippines and Vietnam over the Spratlys and Paracels in the South China Sea.

For China, not only do these waters contain vast strategic resources, they hold critical Sea Lines of Communication (SLOC) for China's maritime trade and energy import from the Middle East and other regions. What is more, as explained above, territorial integrity is at the heart of China's national psyche. So it is no wonder that China is mounting a robust diplomatic and civilian-military response in these troubled waters.

Unfortunately, this comes at a time of resurgent Japanese right-wing politics, capitalizing their political popularity to build a more independently-minded and powerful Japan. Japan's wartime past is being ignored or re-interpreted. A non-repentant stance is adopted on homage to the Yakusuni Shrine housing Japan's war dead and Class A War Criminals. An evasive attitude is displayed over the highly emotionally-charged issue of Asia's "Comfort Women" for the Japanese Imperial Army.

These right-wing leanings have translated into gung-ho foreign, economic and monetary policies. The latest beggar-thy-neighbor strategy of boosting Japan's economy through a massive devaluation of the Japanese yen is an example. There are also political manoeuvres to pave the way for transforming Japan's post-war defence set-up into a more robust military force expected of a "normal" power of the gravitas of Japan.

As a result, relations with China and South Korea have plummeted and alarming signals are being

\footnotetext{
${ }^{7}$ Regional Comprehensive Economic Partnership (RCEP) Joint Statement at the First Meeting of the Trade Negotiating Committee, $\quad$ ASEAN. $\quad$ Retrieved $\quad$ May $\quad 28, \quad$ from http://www.asean.org/news/asean-statement-communiques/item/regional-comprehensive-economic-partnership-rcep-joint-stateme nt-the-first-meeting-of-trade-negotiating-committee
} 
received by Japan's neighbors whose peoples still remember their sufferings under Japanese imperialism. Notwithstanding appearances, tension in the region remains high.

\section{The Importance of Central Asia to China's Energy Security}

China is just beginning to build a blue-water navy with the launch of her first (and outdated) aircraft carrier. Her naval power projection is many decades behind that of the United States. Nevertheless, China's military capabilities are convincing and are seen as increasingly effective for operations over Taiwan. However, they are hardly adequate if China's energy supply sea lanes are to be comprehensively safeguarded. These stretch from the Malacca Strait all the way to the Indian Ocean and beyond, including passage through the Strait of Hormuz near Iran, with multiple choke points beyond China's control.

To ensure energy security, on which China's continued economic development depends, the country has in recent years developed a network of gas and oil pipelines through China-receptive countries in Central Asia (Kazakhstan and Turkmenistan) and in southwest Asia (Pakistan and Myanmar (Gronholt-Pedersen, 2013). According to a report in the Jamestown Foundation (Weitz, 2013), China is building a Eurasian transportation network of rail, highways, and maritime routes. These connect the port of Gwadar in Pakistan to the oil fields in Iran overland and onwards to the energy pipelines in Xinjiang province. There the energy supply is further transmitted to China's industrial eastern seaboard. Given China's substantial interest in energy resources in Afghanistan (Petersen, 2013), this Eurasian energy network is likely to assume even greater importance

A significant anchor of China's energy security is the Shanghai Cooperation Organization (SCO). It was first set up by China and Russia to fight regional terrorism when both countries were increasingly alarmed with "separatist" terrorism. After 9/11, this anti-terrorism remit had a great deal of resonance with the United States. As world geopolitics wore on, the SCO was taking on a wider and wider geographical scope, extending well beyond Central Asia, as well as a greatly expanded agenda encompassing trade, economic, financial, cultural, diplomatic and non-terrorism related military exchanges. As its content and international sphere grew, more and more countries want to join in one form or another. Now, India, Pakistan, Iran, Afghanistan, and Mongolia are Observers; Turkey, Belarus, and Sri Lanka are Dialogue Members; and ASEAN, Commonwealth of Independent States (CIS) and Turkmenistan, are Guest Attendees. Turkey, for one, is interested in becoming a full Member.

What distinguishes the SCO is the significant Islamic representation. At a time of the rise of Islam worldwide, both as a geopolitical force and as growing Islamic economies, this gives the SCO special gravitas to balance the influence of North Atlantic Treaty Organization (NATO) in the region.

\section{The Growing Importance of Africa to China}

Africa accounts for a third of China's crude oil imports and is rich in largely unexploited mineral and other resources. China's footprint in Africa has now become ubiquitous. For the first time in many centuries, in 2012 China surpassed the United States as Africa's largest trading partner with a two-way trade worth \$200 billion. China's state-sponsored financial loans together with various forms of aid, grants, and investments have out-sized those of the World Bank. China's state-run radio and TV network has the largest number of bureaus in Africa than any other country. There are now 28 Confucius Institutes in Africa, and still counting, as well as a "Peace Corp" type program for Chinese young volunteers. 
What is more, there are eight extensive "special economic zones" throughout Africa which are set up by various African states with China's help and management: two in Zambia, two in Nigeria, one in Egypt, one in Ethiopia, one in Tanzania, and one in Mauritius. Extractive industries are likely to remain a key feature except Mauritius, where the emphasis is on building a trading and finance hub in the Indian Ocean. Nevertheless, these zones are open to a host of other investments creating local skills and jobs, including those no longer viable in other parts of the world, including China. Their operations are based on market competition and cooperation with local and international businesses, supported by local government incentives.

China's historical engagement with Africa has undergone many twists and turns, from the early Maoist days of exporting communism, through the Cold War period of rivalry with the former USSR, to winning support for the One China Policy against the influence of Taiwan, to what is now a confident and leading role in helping to re-build much needed health, education, transport and power infrastructure for the whole of Africa. This is, however, accompanied by problems of perceived insensitivity over government corruption, human rights violations, environmental pillage, undesirable labor practices, lack of corporate social responsibility, destruction of local informal businesses, impact on local jobs and a host of other social and economic issues. Some of these opportunities and problems are outlined in China and Africa: A Century of Engagement (Shinn, \& Eisenman, 2012) and The Dragon's Gift: The Real Story of China in Africa (Brautigam, 2009).

\section{The Idea of a BRICS Development Bank}

At a declaration on 27 March 2013 concluding their summit in Durban, South Africa, the BRICS countries agreed to set up a BRICS development bank primarily aimed at Africa. It is too soon to conclude whether the joint venture amongst the BRICS countries can work, as each has its own agenda and some mutual rivalry. The devil is in the detail, still to be hampered out.

Nevertheless, each BRICS member is already proactively engaged in the young continent. If successful, this new BRICS initiative may turn out to be an alternative to balance against the World Bank and the IMF. The latter are often viewed by some developing countries as West-dominated Bretton Woods institutions geared towards the Washington Consensus model of fast-track liberalization and democratization, usually before local conditions are ripe. Past experience is littered with glaring examples of failures as in the case of Argentina during 1999-2002 and Asia during the financial crisis of 1997-1998.

Though their priorities may differ, it is likely that BRICS Members can still bind where it suits them. Given deep pockets and increasing weight in Africa and the rest of the developing world, China is likely to try to win the rapport of the other BRICS members to make the proposed new development bank a credible success story $^{8}$.

\section{China's Military and Security Developments 2013}

The US Department of Defense has released its 2013 Annual Report to Congress on the state and development of China's military. According to the comprehensive report, China has dramatically improved a wide-range of military capabilities including Anti-Access/Area Denial (A2/AD), C4ISR (Command, Control, Communications, Computers, Intelligence, Surveillance and Reconnaissance), survivable long-range nuclear

8 See my commentary BRICS can bind despite differences. Retrieved May 30, 2013, http://www.andrewleunginternationalconsultants.com/chinawatch/2013/04/brics-can-bind-despite-differences-.html 
deterrence, nuclear submarines, guided missiles, stealth fighters, complex-environment information-warfare (IW), cyber warfare, space warfare, and civil-military integration.

The Pentagon Report nevertheless notes that China's military is primarily defensive, in particular over Taiwan and its other territorial claims in the East and South China Seas, as well as guarding vital SLOC. The latter, however, would necessitate the expansion of China's blue-water navy and military projection to distant shores, supported by the development of longer-range transport planes.

Professor Andrew Erickson of the Naval Defense College offers an in-depth assessment of China's military fortes (Erickson, 2013). This highlights China's nuclear-powered ballistic-missile submarines (SSBNs), nuclear attack submarines, the world's only long-range anti-ship ballistic missiles (ASBMs) with a range over $1,500 \mathrm{~km}$, and a probable program of building multiple aircraft carriers. These are said to aim at distant "access points" in the form of agreements for re-fuelling, replenishment, crew rest, and low-level maintenance, possibly in the Malacca, Lombok and Sunda Straits, some of the "choke points" along China's vital sea lanes. The development of a credible blue-water navy is supported by China's world-class shipbuilding and nanotechnology capabilities.

The Report also highlights the efforts of China's military to provide common goods such as anti-piracy, UN peace-keeping operations, and confidence-building joint military exchanges and exercises, including joint operations with the United States and other non-allied nations.

There is little doubt that China now possesses credible deterrence against any aggression, especially critical threats to her "core interests" of national security, territorial integrity, regime stability, and economic development.

The Report also refers to China's identification of the first two decades of the 21 st century as a rare window of opportunity to grow "Comprehensive National Power" in order to attain its status as a global power. It hints at China's increasing interest and capability in projecting power further afield.

The Report emphasizes the need for the United States to remain vigilant in managing US-China relations during China's ascendance in order to safeguard American interests as well as world peace and regional stability in the Asia Pacific.

\section{Brzezinski's Strategic Vision of Global Re-balancing}

In the transformed world of the 21st century, Brzezinski offers a grand strategy for the United States to advance its national interest in his new book "Strategic Vision: America and the Crisis of Global Power" (Brzezinski, 2012).

There are two main strands in Brzezinski's Strategic Vision. The first is that he sees Europe as an inseparable apart of a Western whole which underpins US leadership. He postulates that the US should act as "promoter and guarantor" of a renewed "Larger West" by drawing Russia and Turkey into the European Union (EU) through gradual democratization and eventual conformity with Western norms. Paving the way for Russia to join the World Trade Organization (WTO) would be part of this trajectory. At the same time, rather than downplaying Europe, he emphasizes the importance of deepening the unification of the EU through fostering close cooperation among the key players of France, Germany, and the United Kingdom. The second, and inter-related, strand is the "Complex East", where US best interest would be served by acting as "regional balancer", "replicating the role played by the United Kingdom in intra-European politics during the nineteenth 
and early 20th century".

Seemingly echoing America's "Asian pivot", he suggests that the United States "should help Asian states avoid a struggle for regional domination by mediating conflicts and offsetting power imbalances among potential rivals".

However, contrary to the popular rhetoric of American military power projection in the Asia-Pacific, he points out that "the United States must recognize that stability in Asia can no longer be imposed by a non-Asian power, least of all by the direct application of US military power. Indeed, US efforts to buttress Asian stability could prove self-defeating, propelling Washington into a costly repeat of its recent wars, potentially even resulting in a replay of the tragic events of Europe in the twentieth century. If the United States fashioned an anti-Chinese alliance with India (or, less likely, with Vietnam) or promoted an anti-Chinese militarization in Japan, it could generate dangerous mutual resentment". He recognizes that "in the 21 st century, geopolitical equilibrium on the Asian mainland cannot depend on external military alliances with non-Asian powers".

Instead, Brzezinski advocates that America "should respect China's special historic and geopolitical role in maintaining stability on the Far Eastern mainland. Engaging with China in a dialogue regarding regional stability would not only help reduce the possibility of US-Chinese conflicts but also diminish the probability of miscalculation between China and Japan, or China and India, and even at some point between China and Russia over the resources and independent status of the Central Asian states. Thus, the United States' balancing engagement in Asia is ultimately in China's interest, as well".

It is clear that Brzezinski's Asia consists of a much wider region extending to Central Asia connecting all the way to the "Larger West".

The lynchpin of this realist strategy is a "US-Japanese-Chinese cooperative triangle" to be nurtured through progressive, but lasting reconciliation between China and Japan, similar to that between France and Germany and between Germany and Poland after World War II. In this context, "the guiding principle of the United States should be to uphold US obligations to Japan and South Korea while not allowing itself to be drawn into a war between Asian powers".

"In that context, China should not view US support for Japan's security as a threat, nor should Japan view the pursuit of a closer and more extensive US-Chinese partnership as a danger to its own interests. A deepening triangular relationship could also diminish Japanese concerns over the yuan's eventually becoming the world's third reserve currency, thereby further consolidating China's stake in the existing international system and mitigating US anxieties over China's future role".

What is perhaps the most striking in Brzezinski's China engagement strategy is his recognition of and suggestions for adopting a more accommodative approach to the three sticking points in US-China relations: US reconnaissance operations on the edges of China's territorial waters or within China's economic zone; reciprocal trust-building manoeuvres over US commitments to Japan and South Korea; and a feasible long-term solution over Taiwan in the light of improving cross-Strait relations. Brzezinski suggests that the first of these sticking points be resolved in the near future, the second over the course of the next several years, and the third probably within a decade or so.

Brzezinski's whole rationale is summarized in his opening remarks in his article in Foreign Affairs (January/February 2012, Balancing the East, Upgrading the West-US Grand Strategy in an Age of Upheaval) 
The United States' central challenge over the next several decades is to revitalize itself, while promoting a larger West and buttressing a complex balance in the East that can accommodate China's rising global status. A successful US effort to enlarge the West, making it the world's most stable and democratic zone, would seek to combine power with principle. A cooperative larger West - extending from North America and Europe through Eurasia (by eventually embracing Russia and Turkey), all the way to Japan and South Korea-would enhance the appeal of the West's core principles for other cultures, thus encouraging the gradual emergence of a universal democratic political culture.

Drawing distinction from the historical geopolitics governing the separate fates of the Eastern and Western Roman Empires, Brzezinski opines that in a globalized and inter-connected world, "the West and the East cannot keep aloof from each other: their relationship can only be either reciprocally cooperative or mutually damaging".

It is no coincidence that at this critical juncture of relations between the world's extant superpower and its perceived challenger, President Obama and President XI Jinping chose to meet in a California ranch during 7-8 June. The unspoken agenda is to map out a new mode of engagement to avoid the risks of repeating past world calamities during former periods of global power transition.

\section{Ancient Sino-Turkish Silk Road Links}

According to Rosita Dellios and Nadir Kemal Yilmaz of Bond University in Sino-Turkish Relations in a Globalizing Asia Pacific (Dellios \& Yilmaz, 2008), the early Toba tribe of Turkish-Mongol extraction helped found China's Northern Wei Dynasty in A.D. 386, reuniting China across the northern steppes, the Tarim basin and the North China Plain. Sino-Turkish families were prominent amongst the imperial elite during China's heyday in the Tang Dynasty (A.D. 618-906). From the second century B.C. to the 15th century, the old Silk Road carried busy trade between the China's ancient capital Xi'an and the eastern capital of the Christian world, Constantinople, later Istanbul in the Ottoman Empire. Caravans transported silk and other luxury goods from the Middle Kingdom in exchange for cosmetics, amber, carpets and other products. Exchanges of religious culture such as Buddism and Islam and of technology such as paper and glass also took place.

\section{Philosophical Affinities}

According to the Bond University authors, there is much common ground between China's Daoism and Turkish Sufism (Dellios \& Yilmaz, 2008). Their commonality lies in a willingness to deny pre-conceived notions, a kind of heuristic constructivism, and a yin-yang correlativity in which the importance of identities and understanding is stressed. "A nation's identity is seen as being a work-in-progress through mutual interaction and norm forming" that resists Western scientific predictions (Dellios \& Yilmaz, 2008). This common philosophical leaning which sets great store on interaction with other countries and cultures resonates with both countries' adaptive strategies in an "amorphous world of globalization".

\section{Recent Developments in Turkish-China and China-Middle East Politics and Diplomacy}

Recent high-level visits from Turkey included President Abdullah Gul's two-day visit to Xi'an, starting point of the ancient Silk Road and capital of China's north-western Shaanxi Province, to receive an honorary Ph.D., granted by China's Northwest University in late June, 2009. This was the first by a Turkish president in 14 years.

However, shortly afterwards, when China cracked down on the Uighur riots in Xinjiang in July 2009, 
Ankara reacted strongly by openly condemning the suppression as a "near genocide". This was in keeping with Turkey's de facto guardianship of rights of ethnic Turkic peoples in the Caucasus and Central Asia after the breakup of the Soviet Union. This served to highlight one of Turkey's few sticking points against China.

Nevertheless, not long afterwards, Chinese Premier WEN Jia-bao paid a three-day official visit to Turkey on October 7-10, 2010, the final stop of WEN's European tour that included Greece, Belgium, and Italy. Lauding the start of a new "strategic partnership", the Chinese Premier announced a joint goal to increase bilateral trade from $\$ 17$ billion to $\$ 50$ billion by 2015 and $\$ 100$ billion by 2020 . The China Railway Construction Corporation (CRSS) is constructing a high-speed rail link between Ankara and Istanbul. Prime Minister Erdogan said Turkey intended to build a railway connecting Istanbul to Beijing as part of China's grand plan to connect China by rail to Western Europe via Central Asia and Turkey.

The Chinese Premier's visit was quickly kept up by the visit of Turkish Foreign Minister Ahmet Davutoglu to China from October 28 to November 4, 2010. Davutoglu announced that Turkey plans to expand its diplomatic presence across China by adding more consulates. He appealed to China's core interests by reaffirming Ankara's support of China's "One China Policy" and Turkey's commitment to target any activities occurring in Turkey that may threaten China's sovereignty and territorial integrity, alluding to China's worries over Uighur separatists operating in other countries.

According to Chris Sambelis of the Jamestown Foundation (Sambelis, 2011), Davutoglu's visit followed on the heels of an unprecedented participation by the People's Liberation Army Air Force (PLAAF) in a NATO aerial military exercise, code named "Anatolian Eagle" in the central Anatolian region of Konya from 20 September to 4 October, 2010. This was the first time China's military was involved in such operations on NATO soil. It is noteworthy that the United States and Israel, quite exceptionally, did not participate in this joint NATO exercise. This shows that Turkey's NATO membership does not necessarily preclude closer Turkish-China military relations.

However, differences of opinion or approach to global issues remain between Ankara and Beijing over such issues as the Arab Spring and Syria. In the case of Syria, for example, China prefers adopting a more holistic approach, often siding with Russia, while Turkey leans on the side of its NATO ally the United States.

On the question of Iran, however, China's different approach from the US position could draw Beijing closer to Ankara, according to the Jamestown Foundation author. Apart from a consistent preference for diplomacy rather than resort to coercive force, China has no intention of jeopardizing good relations with her key energy supplier in the Middle East. On the question of Iran, Davutoglu declared during his Beijing visit that "Our views are very close". In this regard, Beijing's efforts to court Ankara are part of a larger strategy to counter Washington's moves in East Asia and other theatres where it sees its interests threatened.

Two ground-breaking top level visits took place in 2012 in cementing Turkish-China relations-the Turkey visit of former Vice President (now President) of the People's Republic of China in February 2012 and Prime Minister Erdoğan's China visit in April 2012, the first by a Turkish Prime Minister in 27 years. These coincided with a "Year of China" in Turkey 2012, to be followed by a "Year of Turkey" in China commencing March, 2013. During his China visit, in addition to promoting trade and tourism, Erdogan urged Chinese leaders to put pressure on Syria to end the violence

All these diplomatic tangos suggest that differences between Turkey and China pale in comparison with 
the huge strategic benefits to both countries from cementing closer ties and from adopting a more flexible and independently-minded direction at a time of rapid change in the world's geopolitical landscape.

It was an eye-opener that for the first time in recent history, President XI Jinping hosted Palestinian President Abbas on 6th and Israeli Prime Minister Netanyahu on 9 May, 2013. This suggests a new Chinese initiative to take a more proactive role in the global commons by offering to help crack the toughest nut in Middle East affairs.

All the above developments augur well that a new era on Turkish-China foreign relations may be dawning as the world's gravitas is shifting back to the silk road that bound ancient civilizations together.

\section{Ten Possible Projects for Turkish-China Cooperation}

As explained above, China remains anxious in gaining access to land-transit-based and less geopolitically-vulnerable commodities and energy supply routes. Additionally, China is likely to continue to seek more outward investment opportunities for her surplus capital to unlock it from a dollar trap of US treasuries. Against this background, the following 10 propositions may present win-win benefits for Turkish-China cooperation.

\section{A New Eurasian Land Bridge}

In a paper dated 27 April 2012 (Engdahl, 2012) for the Centre for Research on Globalization, F. William Engdahl outlines a proposed monumental railway project linking the Port of Shenzhen (near Hong Kong) to Kunming in Western China and onwards to Myanmar, Bangladesh, India, Pakistan and Iran, as well as across Turkey to Rotterdam. Known as the Third Eurasian Land Bridge ${ }^{9}$, the proposed rail network will cross 20 countries in Asia and Europe and have a total length of about 15,000 kilometers, 3,000 to 6,000 kilometers shorter than the sea route via the Indian Ocean from the southeast coast through the Malacca Straits. The total annual trade volume of the regions the route passes through was nearly US $\$ 300$ billion in 2009 . Ultimately the plan is for a branch line that would start in Turkey, cross Syria and Palestine, and end in Egypt, facilitating transportation from China to Africa. This is slated to be part of a grand Chinese vision to connect her dense inland rail connections, including the world's longest high-speed rail network, across the Eurasian Continent, to the Middle East, Western Europe, and Africa. The vision is breathtaking. It is understood that this project was discussed with China's previous Premier WEN Jia-bao during President Erdogan's visit to Beijing in April, 2012. If realized, this grand project would help Turkey to lock into the world's most dynamic market which is also soon to become the world's largest economy.

At the centre of the world supply and production chain China is supported by a host of the world's top container ports along her eastern seaboard. Investment in the Port of Bosphorus at the hub of a burgeoning Eurasian economy should be immensely attractive to China's leading port operators and container port owners.

The Customs Union of Belarus, Kazakhstan, and Russia came into force on January 1, 2010. This will greatly enhance the commercial viability of the 5,000-kilometre highway through Kazakhstan linking China to Europe. This is likely to present opportunities for Turkish and Chinese investments in the physical

\footnotetext{
9 The First Eurasian Land Bridge runs through Russia, connecting Rotterdam to Russia's Trans-Siberian Railway across 13,000 kilometres. The Second Eurasian Land Bridge runs 10,900 kilometers including 4100 kilometers in China, parallel to one of the ancient routes of the Silk Road, linking Kazakhstan and onwards via Russia and Belarus over Poland to the markets of the European Union.
} 
infrastructure and logistics along this vibrant economic corridor.

With the growth worldwide of mobile and other forms of telecommunication, investment in this sector in the dynamic Eurasian region is likely to reap handsome dividends as it takes off economically in the coming decades.

According to Credit Suisse (2013), many of the Central Asian countries along the ancient Silk Road have witnessed an economic renaissance since the turn of the millennium, driven by their rich resources. These include Kazakhstan which is by far the region's best endowed in oil and precious metals; Uzbekistan in agriculture, gold and natural Gas (1\% of global reserve); and Tajikistan. Although Tajikistan relies heavily on its production of cotton and aluminium, its real competitive advantage lies in the vast water supply in its glaciers, lakes, rivers, underground sources, as well as in its nine operational reservoirs containing 15.34 cubic kilometers of water. According to the United Nations Development Program (UNDP), these enormous water reserves represent four percent of the entire world's hydroelectric potential with 520 billion kilowatt hour (kWh) of electricity expected annually for export. Tajikistan has also an abundance of mineral deposits of antimony, mercury, zinc, silver and rock salt.

Istanbul could take advantage of the RMB's internationalization to grow its market share in RMB-based financial instruments including bonds and commercial papers. It may consider expanding the scope of currency swaps and using the RMB for trade settlements with China. Like Japan and Australia, a small percentage of foreign currency reserve may be denominated in the RMB. These initiatives should strengthen the financial links between Turkey and China and help establish Istanbul as a regional financial centre.

China is likely to take a leading role in the establishment of an agreed BRICS development bank targeting Africa initially. One of the likely future initiative of the bank is to seek the participation of commercial capital. As Africa is on the prowl and Turkey has a growing interest in the dynamic continent, the BRICS bank is likely to offer opportunities for Turkish investments on specific projects.

One of the key China initiatives in Africa in the coming decades is the development of "special economic zones" in a host of countries including Egypt, Nigeria, Mauritius (for trade and finance), Tanzania, Ethiopia and Gambia. These are open to foreign investments in a host of manufacturing industries not limited to oil and minerals. Turkish investments in these zones in partnership with China are likely to yield commercial as well as diplomatic dividends

According to the World Tourism Organization, China's outbound tourism, already the world's largest in number of visitors, will reach 100 million visitors by 2015, earlier than the original expectation of 2020 . China's tourists now top the world in spending, amounting to $\$ 102$ billion in 2012 . Turkey is rich in tourist destinations, including many World Heritage sites. It should stand a good chance of attracting more Chinese tourists through improved marketing, upgraded transport facilities, more China-friendly services as well as more imaginative packages e.g. combining sight-seeing in convenient-located venues in neighboring countries.

On the academic, research and cultural fronts, there are likewise many opportunities for cooperation, such as exchange programs and joint research projects between universities; promoting China-Turkish studies, cultural exhibitions, sister-city relationships, joint youth festivals; and establishing a national-level prestigious Turkish think-tank on contemporary China studies 


\section{Conclusion}

From time immemorial, Turkey and China have been linked by blood-line, a heuristic constructionist mindset, trade along the historic Silk Road, and an adaptable approach to foreign relations in keeping with the times. China has vowed to attain the status of a middle-income country with per capita income increasing from $\$ 5,500$ to $\$ 10,000$ by 2020 . Turkey is aiming at renaissance by 2023 , the hundredth anniversary of modern Turkey under Ataturk. As the world is re-balancing amidst epochal changes with Eurasia becoming much more economically and strategically important, both Turkey and China would stand to gain enormously from each other in exploring and pursuing avenues for greater cooperation as partners on a Silk Road to Renaissance.

\section{References}

Acemoglu, D., \& Robinson, J. (2012). Why nations fail. Profile Books.

Annual Report. (2013). Economic outlook-eagles. BBVA, Madrid, March 2013.

BBC News. (2011, March 28). Retrieved June 1, 2013, from http://www.bbc.co.uk/news/science-environment-12885271

Brautigam, D. (2009). The dragon's gift: The real story of China in Africa. Oxford University Press.

BRICS countries path to 2050. (2013). Global Sherpa statistics on globalization, international development and world rankings from a positive, comparative perspective. Retrieved May 25, 2013, from http://www.globalsherpa.org/bric-countries-brics

Brzezinski, Z. (2012). Strategic vision: America and the crisis of global power. Basic Books, November 2012.

China Briefing. (2013). Retrieved May 26, 2013, from http://www.china-briefing.com/news/2013/02/12/china-becomes-worlds-largest-trading-nation-passes-u-s.html

Clinton, H. (2011). America's Pacific Century, Foreign Policy, November 2011. Retrieved May 28, 2013, from http://www.foreignpolicy.com/articles/2011/10/11/am ericas_pacific_century

Cooper, D., \& Hersh, A. (2012). Centre for American Progress and Ann O'Leary, The Center for the Next Generation. The Competition that Really Matters: Comparing US, Chinese, and Indian investments in the next-generation workforce, Centre for American Progress. Retrieved May 26, 2013, from http://www.americanprogress.org/issues/economy/report/2012/08/21/11983/the-competition-that-really-matters/

Credit Suisse. (2013). Commodities super-cycle spur Central Asian growth. Retrieved May 31, 2013 from https://infocus.credit-suisse.com/app/article/index.cfm?fuseaction=OpenArticle\&aoid=238373\&lang=EN

Dellios, R., \& Yilmaz, N. K. (2008). Turkey and China: A study in symmetry. Journal of Middle Eastern and Islamic Studies, 2(1), 13-30.

Engdahl, F. W. (2012). Eurasian economic boom and geopolitics: China's land bridge to Europe: The China-Turkey high speed railway. Centre for Research on Globalization. Retrieved May 30, 2013, from http://www.globalresearch.ca/eurasian-economic-boom-and-geopolitics-china-s-land-bridge-to-europe-the-china-turkey-high -speed-railway/30575

Erickson, A. (2013, May 7). Unpacking the riches of the pentagon's China Report, China Real Time Report. The wall Street. $\begin{array}{llll}\text { Retrieved } \quad \text { May } 28, & 2013, & \text { from }\end{array}$ http://blogs.wsj.com/chinarealtime/2013/05/07/wealth-of-insights-in-pentagon-report-on-chinas-military/

Global Trends 2025: A Transformed World. (2008). National Intelligence Council. Washington D.C., November.

Gronholt-Pedersen, J. (2013, May 12). Myanmar pipelines to benefit China. The Wall Street Journal.

Kharas, H. (2011). The emerging middle class in emerging countries. Brookings Institution, June XX.

Krugman, P. (2009, April 2). China's dollar trap. New York Times. Retrieved May 28, 2013, from http://www.nytimes.com/2009/04/03/opinion/03krugman.html?_r=0

Leung, A. (2013). Enforcing the existing constitution is the best hope for China's democratic reform? Retrieved from http://www.andrewleunginternationalconsultants.com/chinawatch/2013/02/hope-for-green-shoots-of-chinas-democratic-refor m.html

Mahbubani, K. (2013, May 29). Americans ill-served by the blinkered view of US dominance. South China Morning Post.

McKinsey Global Institute. (2008, May 28). Preparing for China's urban billion.

McKinsey Global Institute. (2012). Urban world: Cities and the rise of the consumer class, June.

McKinsey Global Institute. (2013). China's e-tailing revolution, March. 
OECD Report. (2012). Developing economies to eclipse west by 2060, OECD forecasts. The Guardian. Retrieved May 27, 2013, from http://www.guardian.co.uk/global-development/datablog/2012/nov/09/developing-economies-overtake-west-2050-oecd-forecasts

Petersen, A. (2013, April 28). Afghanistan has what China wants, foreign policy. The Afpak Channel. http://afpak.foreignpolicy.com/posts/2013/04/18/afghanistan_has_what_china_wants

Reported in Mail Online of the Daily Mail. (2013). Retrieved May 25, 2013, from http://www.dailymail.co.uk/news/article-1380486/The-Age-America-ends-2016-IMF-predicts-year-Chinas-economy-surpass -US.html

Sambelis, C. (2011). Sino-Turkish strategic partnership: Implications of Anatolian eagle 2010. Jamestown Foundation, 14 January.

Shambaugh, D. (2012). Is China up to the challenge? Yale Global, 21 November 2012. Retrieved May 26, 2013, from http://yaleglobal.yale.edu/content/china-challenge

Shinn, D. H., \& Eisenman, J. (2012). China and Africa: A century of engagement. University of Pennsylvania Press.

Steil, B. (2013). The battle of Bretton woods-John Maynard Keynes, Harry Dexter White and the making of a new world order. A Council on Foreign Relations book. Princeton and Oxford: Princeton University Press.

Subramanian, A. (2012). Eclipse: Living in the shadow of China's economic dominance. Petersen Institute of International Economics, Washington D.C., October.

The Economist. (2012). XI Jinping-The man who must change China. Retrieved from http://www.economist.com/news/leaders/21565210-xi-jinping-will-soon-be-named-china's-next-president-he-must-be-readybreak

Weitz, R. (2013). Beijing builds its Eurasian transportation network, Jamestown Foundation, April $12,2013$. $\begin{array}{llll}\text { Retrieved } \quad \text { May } & 29, & 2013, & \text { from }\end{array}$ http://www.jamestown.org/single/?no_cache=1\&tx_ttnews\%5Btt_news\%5D=40723\&tx_ttnews \%5BbackPid\%5D=13\&cHa $\mathrm{sh}=\mathrm{e} 5941435 \mathrm{c} 14 \mathrm{~d} 7 \mathrm{e} 7 \mathrm{f} 95 \mathrm{e} 0292 \mathrm{f} 3 \mathrm{~b} 02 \mathrm{~b} 41 \mathrm{e}$

World Bank Report. (2012). China 2030: Building a modern, harmonious, and creative high-income society. Development Research Centre of the State Council.

World Intellectual Property Organization (WIPO) Report. (2012). Retrieved June 1, 2013, from http://www.wipo.int/ipstats/en/wipi/

XU, L. Y., \& QIU, J. (2012). Beyond factory floor: China's plan to nurture talent. Yale Global, 10 September. 